\title{
Extension of the use of Augmentoria for Sanitation in a cropping system susceptible to the alien terphritid fruit flies (Diptera: terphritidae) in Hawaii.
}

\author{
Eric B. Jang; LeSter M. KLUngness; Grant T. MCQuATE
}

Pacific Basin Agricultural Research Center, USDA, Agricultural Research Service, P. O. Box 4459, Hilo, Hawaii, 96720, USA

\begin{abstract}
Tephritid fruit flies are a major problem of fruit and vegetable crops throughout the world. Management programs for the control of these pests use a range of techniques, but sequestering fruit to prevent progeny survival is often overlooked. This study reports efforts to demonstrate to growers of fruiting crops a technique to sequester emerging adult flies while conserving their parasitoid natural enemies. Demonstration trials were conducted in 4 phases to determine whether growers on the Island of Hawaii would use a tent-like structure (augmentorium) to sequester fruit-fly infested, culled fruit. In phase 1 it was shown that 1127 Bactrocera cucurbitae (Coquillett) were recovered from cull fruit removed to the augmentorium, and that the combination of bait spray, male lure trapping and sanitation could reduce the level of infestation. Subsequently phase 2 confirmed the three techniques disrupted the breeding cycle and 2 farmers were convinced to use these techniques. In phase 3 , further expansion to 12 farms, whose 15 augmentoria were monitored, indicated that over $80 \%$ of the growers used the tents $(22,217$ adult flies recovered from the tents over 1260 days). In phase 4, success of phases 1 to 3 convinced 30 farms to requested 40 augmentoria and an opinion survey of those growers is reported. Implications for use of augmentoria to sequester other insect pests and release their natural enemies, is discussed.. @JASEM
\end{abstract}

Since the advent of broad-spectrum pesticides, they have been used against tephritid fruit flies (Diptera:Tephritidae) in Hawaii (Kaiser, 1968, Ebling et al. 1953). No systemic toxicant has been approved in Hawaii for use on edible crops at the fruit-bearing stage because fruit fly damage occurs so close to harvest that there is no time for pesticide residuals in the fruit to dissipate. Research had indicated that combining bait with pesticide could only reduce the fly infestation rate to ca.15\% (Nishida \& Bess, 1950, Nishida et al 1957, Nishida, 1954 \& 1958). Recent field comparisons of a new bait using a safer insecticide of biological origin (spinosad) combined with a food bait [GF120 Naturalyte ${ }^{\mathrm{TM}}$ (Dow Agrisciences Inc., Indianapolis, IN) make it possible to apply bait to within 4 hours of harvest. However, GF120 Naturalyte ${ }^{\mathrm{TM}}$ is only effective against feeding flies (Miller et al. 2004, Prokopy et al., 2003 and 2005), and only if used consistently throughout the fruiting and post fruiting season (Revis et al. 2004).

Reliance on pesticides has led to the highly persistent problem of fruit fly infestation in Hawaii because 1) a proportion of gravid females always managed to avoid the pesticides and baits (Klungness et al. 2005); 2) the net survival rate for B. cucurbitae is 317.5 progeny per adult (Vargas et al. 1984); and 3) pesticides have discouraged field sanitation. This leads to rapid recovery of the fly population. Melon flies only infest ripe papaya which usually been left on the the ground (Liquido, 1991 a \& b). The removal of this ground fruit effectively reduces infestation (Liquido, 1993. Brazilian and Costa Rican producers are required to practice sanitation and meet other requirements to qualify to export their papaya fruit to the United States (Mackey 1998). Hawaiian growers have been under quarantine for 50 years but no protocols for field sanitation have been developed to allow export to the continental United States or other countries.

Several species of braconid parasitoids, including two egg-paraistoid species of the genus Fopius $[F$. arisanus (Sonan) and $F$. vandenboschi (Fullaway)], were introduced into Hawaii in the late 1940's. After five years, these wasps were able to parasitize only $60 \%$ of $C$. capitata and $40 \%$ of B. dorsalis in coffee in Kona (Haramoto and Bess, 1970). Refugia (larvae burrows into the fruit so that they are out of reach of the parasitoids) are important barriers to successful parasitism. F. arisanus was the most successful, because it can oviposit before the larvae burrow into the fruit (Purcell et al. 1994a). Only one of the introduced parasitoids, Psyttalia fletcheri, can reproduce in Bactrocera cucurbitae (Vargas et al. 2004), and because it is a larval parasitoid, is only marginally successful at circumventing refugia (Purcell \& Messing 1996a). Tetrastichus giffardianus (Hymenoptera: Eulophidae) has a low parasitism rate in melon fly, but it is so small it can enter larval tunnels and parasitize fruit flies deep within the fruit (Purcell at al. 1996b). Nevertheless, organophosphate pesticide application limits the survival of parasitoids (Purcell el al. 1995).

Observations of the need to protect parasitoids (Purcell et al.1994b; Purcell 1998) led Klungness and Messing (1999) to propose a Low Input Sustainable Agriculture grant from the University of Hawaii to create a structure where infested fruit could be sequestered from the crop so that the emerging adult flies could not escape, yet the parasitoids could emerge and escape. As part of the USDA-ARS sponsored Hawaii Area Wide Fruit Fly Integrated 
Pest Management Project (2000-2007), these structures (called augmentoria, singular augmentorium) were deployed to test hypotheses about the effectiveness of chemical, mechanical and other methods of killing post-oviposition larvae in the fruit (Klungness et al. 2005).

The objective of this Area Wide Project demonstration was to encourage the use of augmentoria as a sanitation tool. The null hypotheses were that growers would not adopt augmentoria for sanitation and there would be no impact of sanitation on fruit fly emergence.

\section{MATERIALS AND METHODS}

Phase 1: initial on-farm demonstration: Late in 2000, the first field phase was undertaken using an augmentorium at a mixed vegetable farm (hereafter referred to as Farm 1) in Lalamilo Agriculture Lots (an area of ca $3.5 \mathrm{Km}^{2}$ ) in the town of Kamuela, Hawaii. This farm practiced rotation planting of primarily leaf crops, sweet pepper, watermelons and cantaloupe. The leaf crops were planted year round, whereas the cucurbit and solanaceous crops were planted for several rotations in the spring and summer.

One augmentorium was deployed in a field of 0.8 hectares of watermelon and cantaloupe. Four suppression techniques were applied: 1) the field was surrounded with 12 Cuelure (4-[p-Acetoxyphenyl]-2-butanone) (Scentry Biologicals, Billings, MT) traps to attract male melon flies (monitored weekly); 2) eight Protein bait traps consisting of yellowbottom dome traps (Great Lakes IPM, Inc., Vestaburg, MI) containing Solulys AT bait (Roquette America, Hollander Distribution, Bridgeview, IL) were placed within the crop (monitored weekly); 3) weekly applications of GF120 Naturalyte ${ }^{\mathrm{TM}}$ bait spray were made; and 4) damaged fruits were culled and placed into an augmentorium weekly from the first flower set in December 2000 until April 2001, and less frequent thereafter. Two Solulys-baited dome traps were placed in the augmentorium and sampled weekly. Flies in the cuelure and Solulys traps were counted and sexed.

Throughout this time baseline data was being collected from 9 trap sites in the ca. $3.5 \mathrm{Km}^{2}$ area of Lalamilo Farm lots, where Farm 1 is located. Cuelure traps and protein bait traps from these sites gave a representative sample of the flies emerging from wild and commercial host plants throughout Lalamilo during first 2 extension phases.

Subsequently Farm 1 continued to cooperate with the USDA-implemented control program. Besides allowing the USDA to deploy and monitor male annihilation traps, the grower accepted 2 additional augmentoria to service the 11 different fields where cucurbit crop rotations occurred.

Phase 2: Second on-farm demonstration: In order to convince the grower in Farm 2 that the culled zucchini fruit left in his field caused an increase in fly population, we initiated a second demonstration in Lalamilo Farm lots. The grower had been applying dimethoate to kill the adult flies, but was overwhelmed by the level of infestation. Therefore, he tilled the crop under with a tractor roto-tiller, and agreed to the placement of an augmentorium over a $4.6 \mathrm{~m}^{2}$ area of the crop in the freshly roto-tilled field. The flies emerging in the augmentorium, trapped in dome traps containing Solulys bait, were counted and sexed.

After this initial phase, Farm 2 agreed to have 2 augmentoria, and the USDA workers were allowed to deploy protein bait and cuelure traps on his farm.

Phase 3: Expansion to other Kamuela farms; In this phase of the project, based on the success at Farm 1 and 2, 15 augmentoria were deployed at twelve farms and gardens of various size and productivity throughout South Kohala District on the island of Hawaii. Maost, of these augmentoria were monitored on a relatively frequent basis with solulys-baited dome traps placed inside the augmentoria. The flies were counted by species and sexed.

Phase 4: Expansion to the whole island: In this phase augmentoria continued to be deployed at as many farms as were willing to participate. Eventually, 40 augmentoria were deployed at 30 farms around the island of Hawaii. These cooperators were sent survey forms to determine their attitudes and level of involvement in the fruit fly control strategy. Survey results were analyzed using the $\mathrm{SAS}^{\circledR}$ procedure FREQ (SAS Institute, Cary, NC).

\section{RESULTS}

Phase 1: When compared to baseline fly populations (Fig. $1 \mathrm{~A})$, the results of this phase gave preliminary indications that the combination of sanitation, lure trapping and baitpesticide spraying could reduce a large population of flies to a very low level (Fig. 1 B). It is apparent (from the 1127 flies that eclosed in the augmentorium over the 181 days of the trial) that the initial population of flies ( 804 by 2 Feb., 2001) might have been perpetuated by their progeny were it not for sequestering fruit in the augmentorium from the time of first fruit set. A second, but much reduced, surge in fly population at the end of February occurred, in spite of the intensive sanitation, bait-pesticide spraying and trapping. Nevertheless, by the end of April the fly population in the melon field had declined to near zero, and it did not begin to recover (as measured by the flies emerging from the culled fruit in the augmentorium) until late June (ca. 2 months after the termination of the GF-120 fruit fly bait sprays). In contrast, baseline protein baits were catching 0.28 FTD on Jun $5^{\text {th }}$ and peaked at 0.40 FTD on Jul $3^{\text {rd }}$.

Prior to this demonstration, the experience of the grower (personal communication) had been that there would always be a gradual but continuous increase in fruit fly damage in spite of the application of a malathion cover spray, with or without NuLure bait (John Taylor Fertilizers, Dixon CA), to the crop. This observation is supported by previously reported experiments conducted in augmentoria (Klungness et. al. 2005).

This grower (Farm 1) continued to cooperate with the Area Wide Program for the following 3 years. However, the effect of this first demonstration was to illustrate the combined impact of the treatments. The sanitation 
component was conducted by the USDA workers, and was not adopted by the grower at that time. The grower did agree to assume the responsibility for the bait spraying. Other techniques, such as lure trapping, protein bait trapping, sterile insect technique, and augmentative release of parasitoids were being applied in stages by the USDA staff, and field populations of melon fly at Farm 1 were monitored throughout the period of cooperation (Jang el al., unpublished data).

As the grower at Farm 1 became more confident that the melon fly problem was controllable, he attempted to continue rotation plantings of melons into the winter. When it was apparent that the cool temperatures between October and February stunted the growth of the melon crops, he decided to try a crop they had not grown for several years. The grower stated that zucchini had previously proven to be too difficult to grow because the application of organophosphate pesticides did not stop the increase in melon fly population. With the new suite of techniques introduced by the USDA program, the grower found he could continue production of zucchini year round.

As the grower became more aware of the important part sanitation plays in the control of melon fly population buildup, he instructed the worker in charge of zucchini production to use the augmentoria (Fig $2 \mathrm{~A}$ ) for sanitation (Fig 2 B). The worker did this with alacrity, as indicated by the 9719 eclosed adult flies recovered from the three augmentoria on that farm (Fig. 3 A). Note that the number of flies per protein bait trap per day in those zucchini fields exceeded 0.5 only once during this period of intensive sanitation.

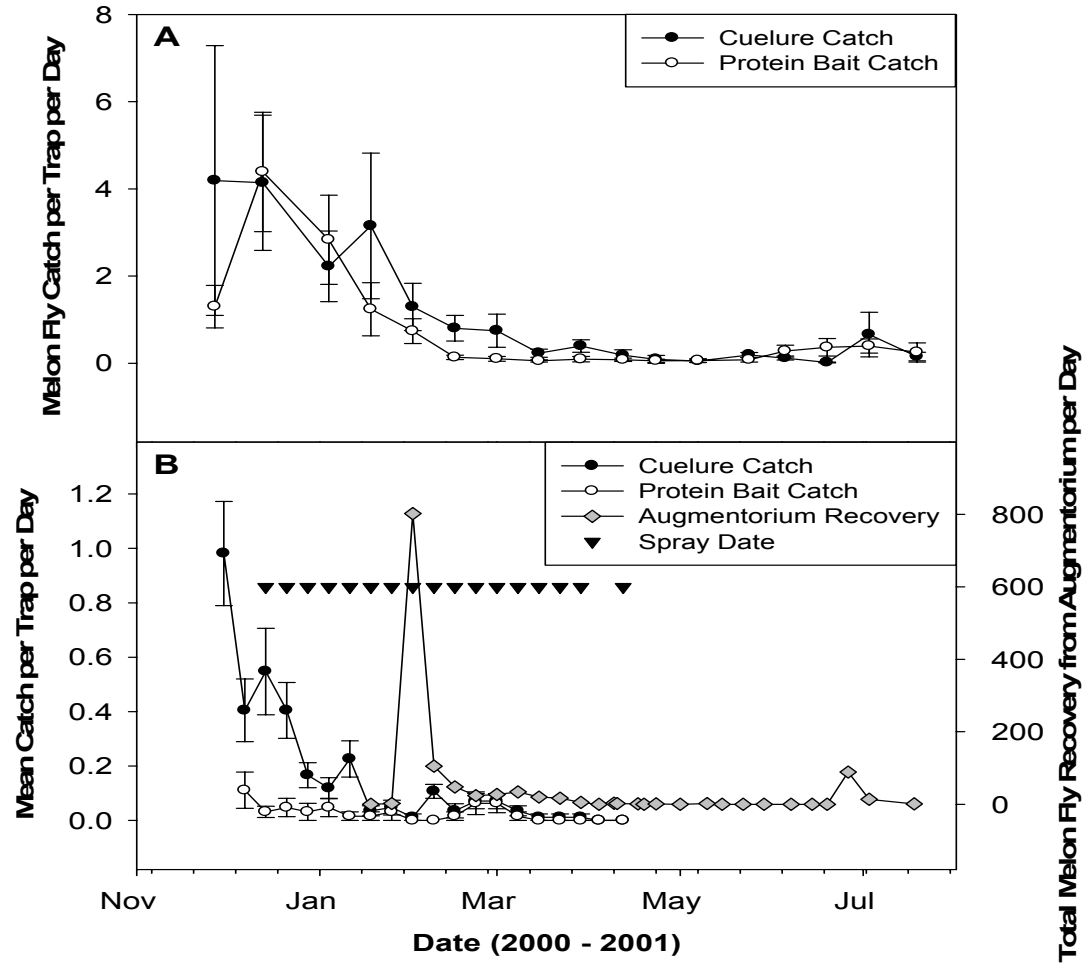

Fig. 1. A Melon fly catch per trap per day $( \pm$ SEM) in traps baited with cuelure, or with protein bait, and deployed at the untreated Lalamilo Farm Lots (ca. $3.5 \mathrm{~km}^{2}$ ), surrounding the site of the suppression trial (Farm 1). B Melon fly catch per trap per day ( \pm SEM) in traps baited with cuelure, or with protein bait, and deployed at the site of the suppression trial (Farm 1). Also shown are dates of application of GF-120 Fruit Fly Bait and the total recovery per day of melon flies which emerged from fruits sequestered in the augmentorium.

Whereas prior to the program, it was the practice of the grower to plant at one time in one area, and then move the next planting of that crop to an area $>300 \mathrm{~m}$ from the first, the grower was now able to plant staggered sequential plots of zucchini in the same location $(0.8 \mathrm{ha})$ for 5 months (Fig. 2 C). This facilitated steady production for his market, but would have caused build up of fruit fly population without the 1-2-3 suppression measures. Particularly effective sanitation was being achieved in the summer of 2003, with 2928 flies caught in the augmentoria between May $1^{\text {st }}$ and Jul $24^{\text {th }}$. Due to labor shortages in 2004, the grower instructed the worker to return to less careful sanitation indicated by the capture of only 421 flies in the augmentorium between Jan $1^{\text {st }}$. and Mar $9^{\text {th }}$. This led to resurgence of the in-field melon fly population which peaked at 3.75 flies/trap/day in protein bait traps on Feb 92004 (Fig. 3 A). Bait spray application and lure trapping remained at an approximately constant rate throughout this period. In addition to the grower's infield applications of GF120, USDA staff applied ca. 
10 liters of GF120 concentrate per week to hot spots within the $40 \mathrm{Km}^{2}$ grid between Apr 2002 and Nov,
2004. SIT and parasitoid releases had been discontinued by 2004 .

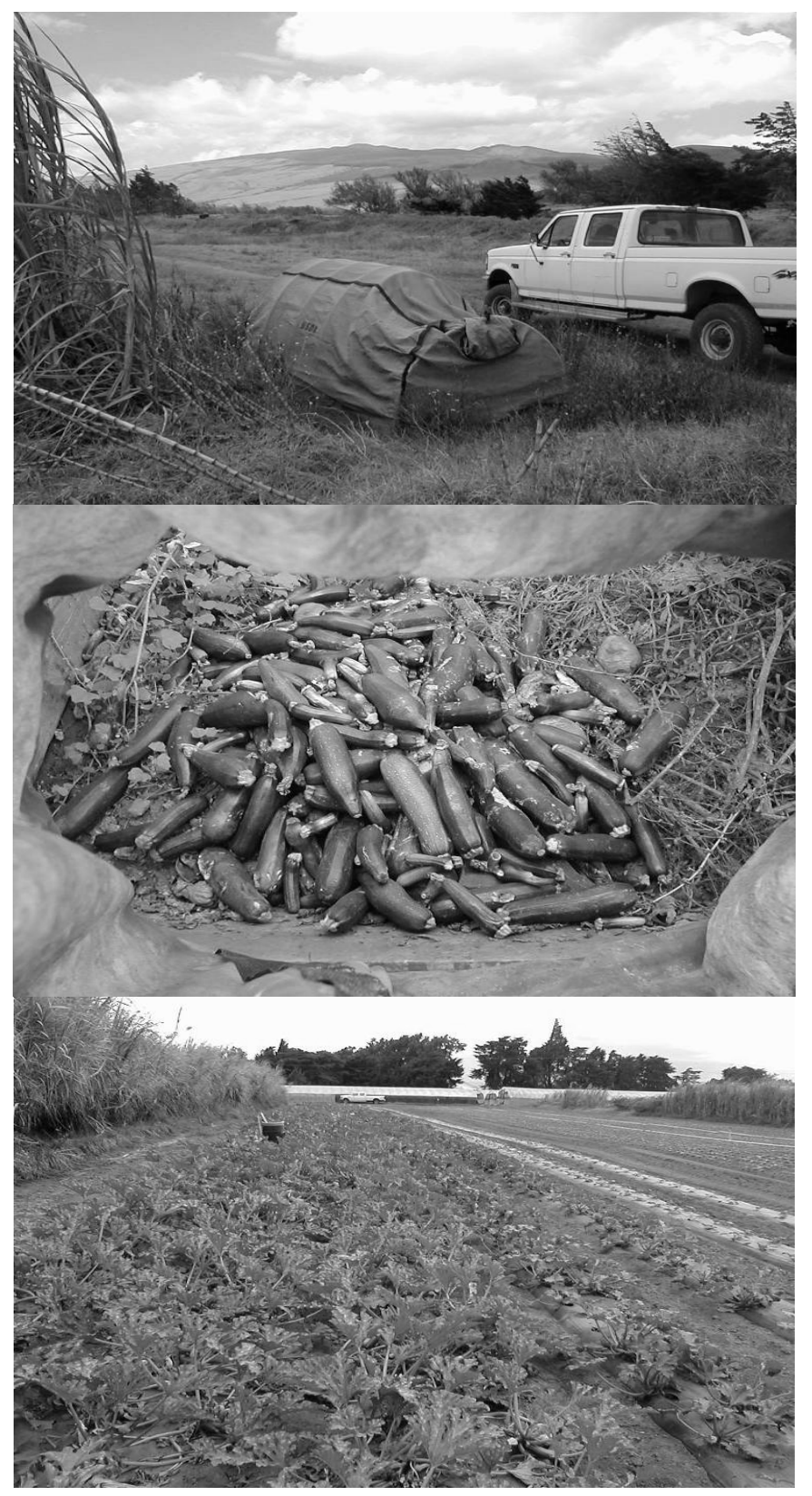

Fig. 2. A . Augmentorium deployed at Farm 1 near zucchini planting.; B View of culled zucchini fruit in the agumentorium at Farm 1. C. Shows sequential plantings of zucchini under thorough sanitation, male trapping, and bait spray treatment.

At Farm 1, the crew that was responsible for melon harvesting was not cooperative about disposing of damaged fruit. The two most probable explanations for their attitudes are: 1) it is damaging to the vines to walk through a cantaloupe or watermelon planting to cull infested fruit, and/or 2) fruit flies, as well as other sources of fruit damage such as anthracnose disease, cause the melons to rot and be unpleasant to handle. Toward the end of the three years, the largest increase in melon fly populations occurred around these melon crops (Fig 3 B), with a peak protein bait trap catch of 7.5 flies/trap/day on Feb 6 2004. This occurred despite well separated field planting of melons, whereas zucchini was sequentially planted in the same field. Field sanitation had been much more successfully applied to the zucchini crop. 
Phase 2: From the augmentorium placed over $4.6 \mathrm{~m}^{2}$ of tilled ground at Farm 2, the total melon fly catch (1278) was larger than what had been collected at Farm 1 from 0.8 ha of melons over a complete cropping cycle in phase 1 . This reservoir of flies from infested culled fruit occurred in spite of applying pesticide and tilling the field. This demonstration was very convincing for the grower, and he asked us to deploy 2 augmentoria for his crop. From that point the grower placed most of his culled fruit in the augmentoria. The sequence of fly eclosion in his augmentoria (over the 1251 days that they were monitored) is illustrated in Fig. 4 A. His peak catch in the augmentoria (1524 flies on Sep. 4 2002) followed his peak protein bait catch in the crop (2.0 flies/trap/day on Aug. 13 2002). During the 899 days of monitoring protein bait catch in the crop, flies per trap per day exceeded 0.5 only 5 times, but in each case the population quickly declined.
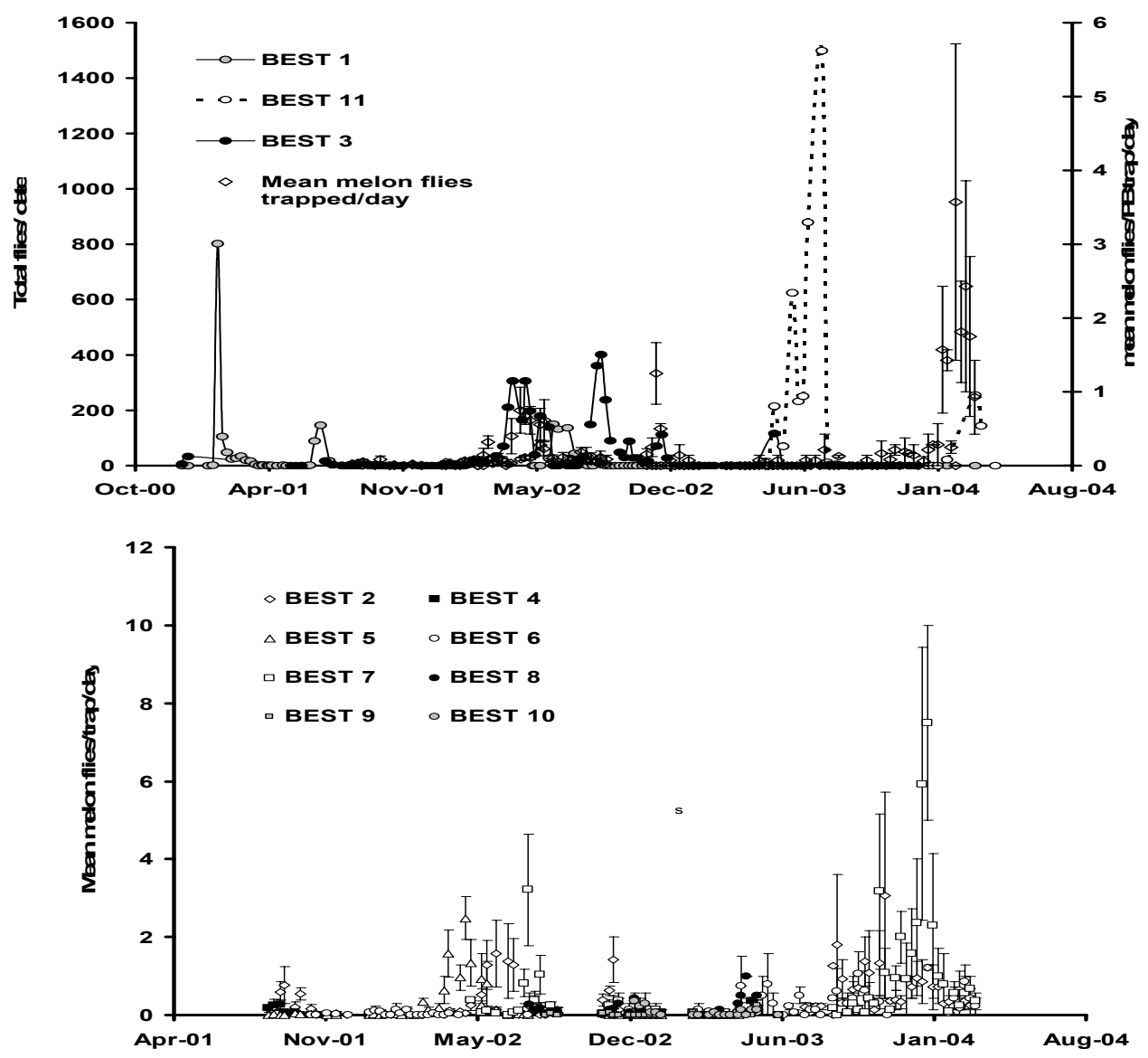

Fig. 3. A Total emergence of B. cucurbitae over time from 3 augmentoria placed in 3 BEST (Farm 1) fields listed in the legend. The source of the cull fruit could have been any of 11 fields to which cucurbit and solanaceous crops were rotated, but were more likely to be from these 3 fields. These fields produced primarily zucchini. Protein bait trap data for these fields is overlaid as mean \pm s.e.m. of melon flies/trap/day. B Mean \pm s.e.m. of the number of melon flies trapped in protein bait traps per day in 8 fields at Farm 1. These fields were predominately planted with watermelon and cantaloupe crops, in which sanitation was generally not practiced. This resulted in higher in-field fly populations in spite of male trapping and bait spraying.

This grower also assumed responsibility for the application of bait sprays. He began planting a series of squash crops, diversifying into yellow zucchini and crook-necked yellow squash, which are both very attractive to melon fly. Previous to the introduction of the 3 suppression methods, heavy losses to melon fly infestation prevented such yellow squashes from being grown successfully. By the use of timely bait spraying and good sanitation, this grower has been able to continue production of these squashes almost continuously for 3.4 years. In the summer of 2002 , over-production forced the grower to discard 40 cases of fruit by digging a trench and burying the boxes of fruit 2 feet under the soil. In the subsequent 2 years, this grower was able to develop a management system that has maintained very low levels of fruit fly damage. This is apparent from both the augmentoria and field protein bait trap data (Fig 4A). Because 
nearly all of his culled fruit went in the augmentorium (greatly reducing the risk of in-field infestation), a total of 8872 flies emerged in this farm's 2 augmentoria over the time they were monitored. An average of 84.7 flies/month emerged from fruit collected from ca. 1 ha. In 2003 this grower (Farm 2) was the first to take over the servicing of his male annihilation traps. Monitoring by the government staff indicated low levels of melon fly population in Farm 2 (Fig. 4 A). The population increase in the summer of 2002 was quickly reduced by the grower's judicious use of the augmentorium and regular GF120 applications. Flies increased in the field around the augmentorium in Feb 2004, because field mice chewed holes in the augmentoria screen. These were repaired and the population soon declined. Comparing baseline fly populations (Fig. 4 B) to mean fly catch in Farm 2, the latter exceeded the former 4 times between 2001 and 2004. Nevertheless the in-farm mean remained < 0.5 FTD except in Dec.2002 and Mar. 2004.

Phase 3: The average catch of melon flies over the 12 properties where augmentoria were deployed was
$31.1 \pm 3.3$ flies per sampling date (Fig. 5). A total of 21,214 eclosed flies were recovered from all 15 augmentoria. Only one grower (Farm 5) refused to use the augmentoria, but these data are an average of the 14 properties where the augmentorium was used once or more to discard fruit. Farm 4 dumped only citrus in his augmentoria. Fruit acidity prevented fly emergence. Of these, the growers with whom the USDA staff worked most closely were the ones that were most likely to use the augmentoria. Mean and total melon fly catch in the augmentoria are graphed over time in Fig. 6. The more cooperative growers also proved to be the growers most willing to use the other fruit fly control techniques.

Phase 4: As the deployment of augmentoria was expanded to the entire island of Hawaii, 35 willing cooperators were enlisted. The growers were assigned a number which is roughly based on the order in which they acquired the augmentoria. A questionnaire mailed to all of these cooperators yielded at $36.6 \%$ survey response. (Table 1 ).

\begin{tabular}{|c|c|c|c|c|c|c|c|}
\hline $\begin{array}{l}\text { Eleven } \\
\text { responses out of } \\
30 \text { who received } \\
\text { augmentoria }\end{array}$ & $\begin{array}{l}\text { Acres owned } \\
\text { by respond- } \\
\text { ents }\end{array}$ & $\begin{array}{l}\text { Tree crops } \\
\text { reported }\end{array}$ & $\begin{array}{l}\text { Acres of } \\
\text { trees } \\
\text { reported }\end{array}$ & $\begin{array}{l}\text { Acres of } \\
\text { fruiting } \\
\text { veget-ables } \\
\text { reported }\end{array}$ & $\begin{array}{l}\text { Total months } \\
\text { of augment- } \\
\text { orium use }\end{array}$ & $\begin{array}{ll}\text { Percent } & \text { of } \\
\text { augmentorium } & \text { was } \\
\text { sanitation. } & \end{array}$ & $\begin{array}{r}\text { time } \\
\text { used for }\end{array}$ \\
\hline Total & 110.5 & 222 & 11.35 & 28.96 & 114 & \multicolumn{2}{|l|}{67.3} \\
\hline $\begin{array}{l}\text { Mean } \\
\pm \text { s.e. } \\
\% \text { who used } \\
\text { agumento-rium }\end{array}$ & $\begin{array}{l}10.0 \\
\pm 3.9 \\
\% \quad \text { who } \\
\text { reported } \\
\text { previous } \\
\text { infesta-tion }\end{array}$ & $\begin{array}{l}37.0 \\
\pm 23.6 \\
\% \text { who use } \\
\text { male lure } \\
\text { traps }\end{array}$ & $\begin{array}{l}5.675 \\
\pm 0.68 \\
\% \text { who use } \\
\text { GF120 bait } \\
\text { spray }\end{array}$ & $\begin{array}{l}3.62 \\
\pm 1.9 \\
\text { \% } \\
\text { it who had } \\
\text { tilled crop } \\
\text { after } \\
\text { harvest }\end{array}$ & $\begin{array}{l}10.43 \\
\pm 3.4 \\
\% \text { who had } \\
\text { piled fruit on } \\
\text { compost pile }\end{array}$ & $\begin{array}{l}\% \text { who had sent } \\
\text { culled fruit to } \\
\text { county landfill }\end{array}$ & $\begin{array}{l}\% \text { who } \\
\text { buried } \\
\text { culled } \\
\text { fruit }\end{array}$ \\
\hline $\begin{array}{l}100.0 \\
\mathrm{Pr}> \\
|\mathrm{Z}| \\
0.0009 \\
\text { Proportion of the } \mathrm{c}\end{array}$ & $\begin{array}{l}81.8 \\
\mathrm{Pr}> \\
|\mathrm{Z}| \\
0.0348 \\
\text { ontrol the growe }\end{array}$ & $\begin{array}{l}100.0 \\
\mathrm{Pr}> \\
\mathrm{ZI} \\
0.0009 \\
\text { s attribute to }\end{array}$ & $\begin{array}{l}100.0 \\
\mathrm{Pr}> \\
|\mathrm{Z}| \\
0.0009 \\
\text { arious suppre }\end{array}$ & $\begin{array}{l}9.1 \\
\mathrm{Pr}> \\
|\mathrm{Z}| \\
0.0067 \\
\text { ession techniques }\end{array}$ & $\begin{array}{l}36.4 \\
\mathrm{Pr}> \\
|\mathrm{Z}| \\
0.3657\end{array}$ & $\begin{array}{l}18.2 \\
\mathrm{Pr}> \\
|\mathrm{Z}| \\
0.0348\end{array}$ & $\begin{array}{l}27.7 \\
\operatorname{Pr}> \\
|z| \\
0.1317\end{array}$ \\
\hline $\begin{array}{l}\text { Suppression } \\
\text { techniques: }\end{array}$ & augmentorium & $\begin{array}{l}\text { Other } \\
\text { techniq }\end{array}$ & $\begin{array}{l}\text { santiation } \\
\text { ues }\end{array}$ & $\begin{array}{l}\text { Bait and } \\
\text { lure } \\
\text { controls }\end{array}$ & $\begin{array}{l}\text { rcent of Grow } \\
\text { it spray, SIT \& }\end{array}$ & $\begin{array}{l}\text { in zone of USDA } \\
\text { iocontrol }\end{array}$ & rea Wide \\
\hline $\begin{array}{l}\% \text { of impact } \\
\text { perceived by } \\
\text { grower } \pm \text { s.e. }\end{array}$ & $\begin{array}{l}38.0 \\
\pm 3.5\end{array}$ & $\begin{array}{l}34.0 \\
\pm 5.2\end{array}$ & & $66.0 \pm 6.0$ & $45.5 \% \mathrm{Pr}>$ & $|z| 0.3657$ & \\
\hline
\end{tabular}

\section{DISCUSSION}

The results of these demonstration phases support the conclusion that both null hypotheses are false. Some growers will use augmentoria for sanitation, and sanitation can impact fruit fly emergence. Assuming a sex ratio of ca. 50:50, the 21,214 melon flies trapped could have produced $3,367,722$ progeny in the first generation. Because conditions within an augmentorium loaded with fruit do not promote survival of all larvae to the adult stage, it is probable that the number of larvae sequestered was even greater. During these demonstration trials, ca. 250 cuelure trap caught an average of ca. 115 male melon flies/trap (Jang et. al., unpublished data). In the same time period 15 augmentoria caught ca. 1414 male and 
female flies/augmentorium. The more astute grower will recognize the need to break this exponential phase of the breeding cycle. In addition to the augmentorium, other techniques (e.g. bagging or drowning fruit, or removal of fruit to landfill, compost and animal feed) are often employed to remove infested culled fruit from the growing environment.
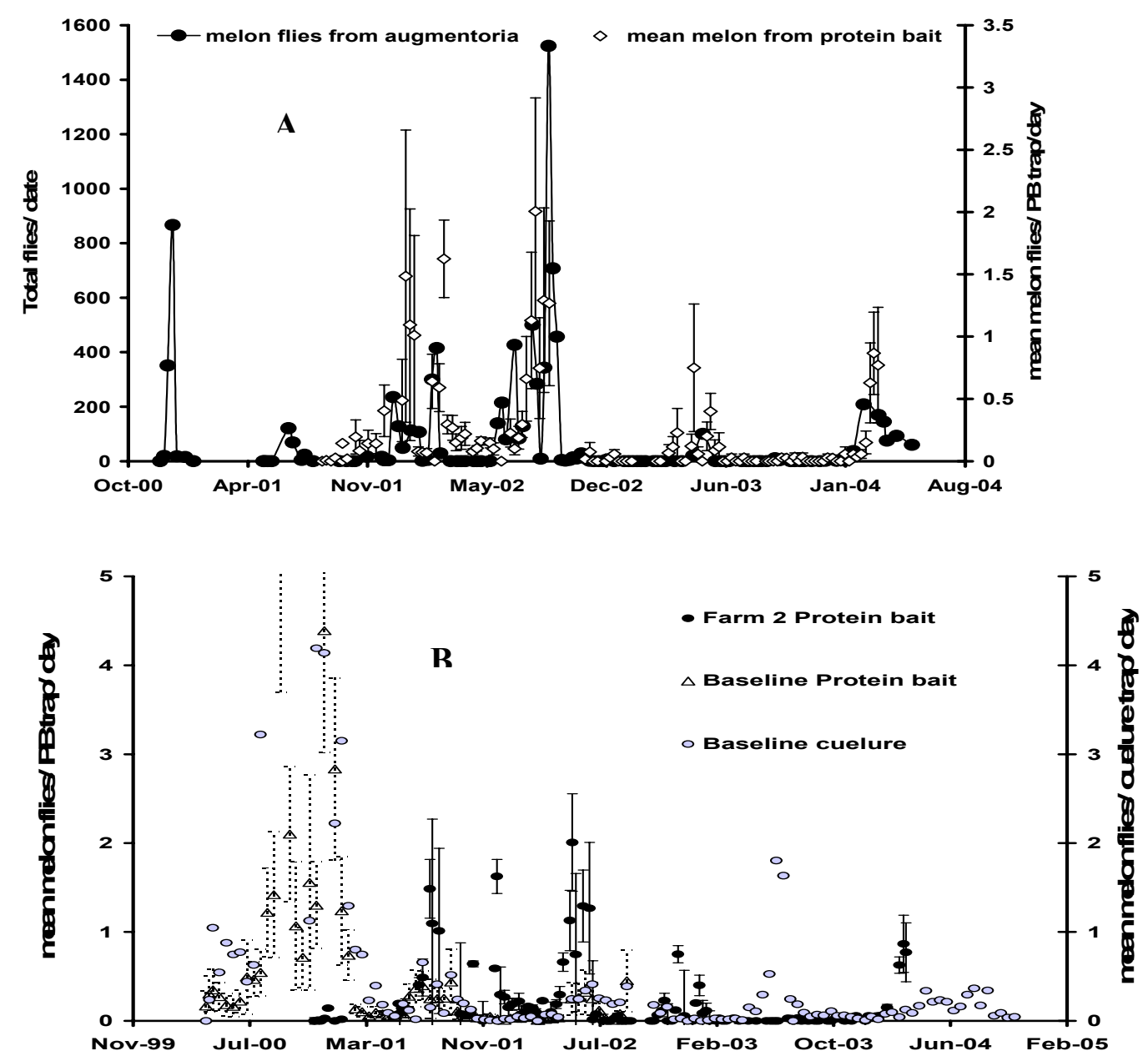

Fig. 4. A Total emergence of B. cucurbitae over time from 2 augmentoria on Farm 2. The source of the cull fruit would have been any of 5 fields to which cucurbit crops were rotated. Protein bait trap catch mean \pm s.e.m. from all 5 fields in which cucurbits were being grown is overlaid. B. Mean \pm s.e.m. of protein bait trap catch within Farm 2 is compared to baseline protein bait catch and baseline cuelure catch.

Not all situations will be conducive to the use of augmentoria, but the labor involved in loading infield augmentoria compares favorably to removing culled fruit from the field and disposing of it elsewhere. This is particularly true where mechanization of the process is prohibitive, such as in very small farms, orchards with closed canopies (not accessible to mechanized fruit haulers), and areas where labor cost are low. Through the application of the three readily available fruit fly suppression techniques (sanitation, protein bait spraying and male annihilation with lures), the Area Wide Program has restored production of some crops that could not be grown in Hawaii in previous years. (Vargas et al. 2003).
Several of the growers in this study believed that the preservation of parasitoids is an important reason to use the augmentoria. The unique feature of the augmentorium is that it offers the possibility for parasitoids to emerge and escape into the crop environment. This principle may be applied to other species of pest insects as well, because the parasitoid is often smaller than its host. By selecting a screen dimension that restricts the host and permits the passage of the natural enemy, biological control of the host can be enhanced. For example, pickleworm, Diaphania nitidalis (Stoll), has recently invaded Hawaiian cucurbit crops. Disposal of infested fruit in the augmentorium used for fruit flies, will also 
sequester emerging adult pickleworm, and has potential to allow the development and release of several of its parasitoids (Capinera, 2005). Although a portion of the mango weevils, Cryptorhynchus (=Sternochetus) mangiferae (F.), emerge from the fruit before harvest (Follett and Gabbard, 2000), if the weevil is still in the damaged fruit when placed in an augmentorium, those weevil progeny will be effectively prevented from re-infesting the crop (Griesbach, 2003).

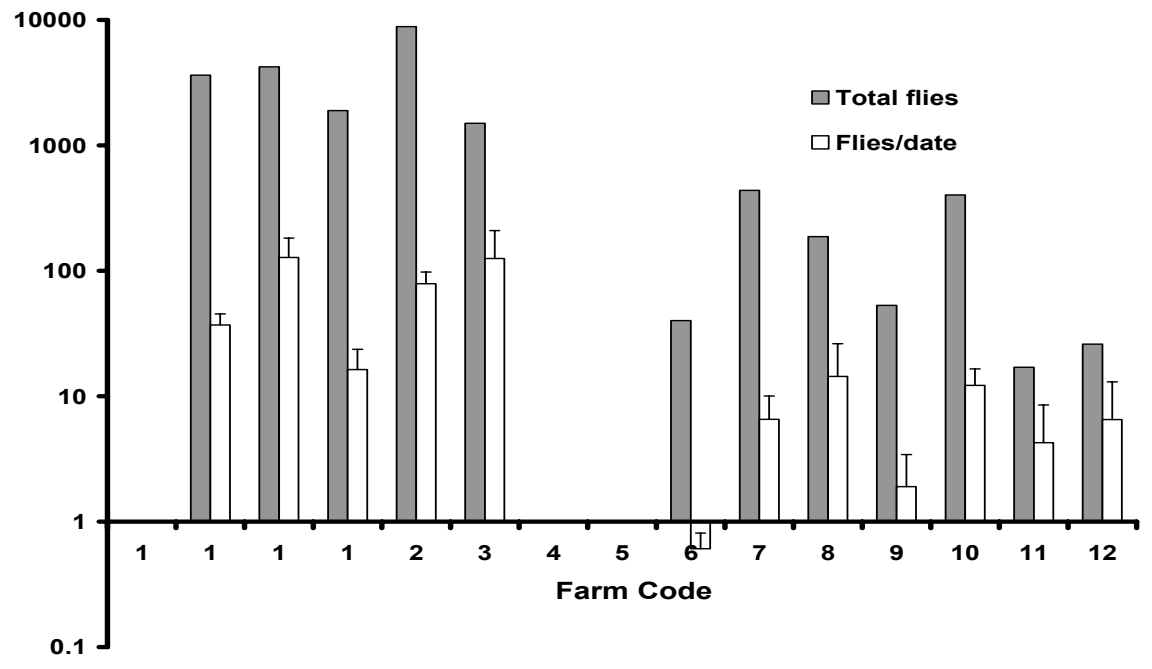

Fig. 5. Natural log of total and mean \pm s.e.m. emergence of melon fly from each of 15 augmentoria on 12 farms in North and South Kohala.

Acknowledgement: We acknowledge Robert Faust, Director of the USDA-ARS Area Wide Program for providing funding, and Roger Vargas for supporting the development of sanitation in the Hawaii Area Wide Fruit Fly Integrated Pest Management Program. We also acknowledge all of the growers who cooperated in these trials, with particular gratitude to Earl Yamamoto, Luis Rincon, and Terry Weaver for their contributions to the augmentorium sanitation trials, the efforts of the USDA staff who monitored the augmentoria and field traps, Tadao Urago, Matthew Hiramoto, Preston Sato, Cheryl Chan and Donna Ota, and the critical reviews of this paper by Jari Sugano, Timothy Holler, Robert Dowell and Luc LeBlanc.

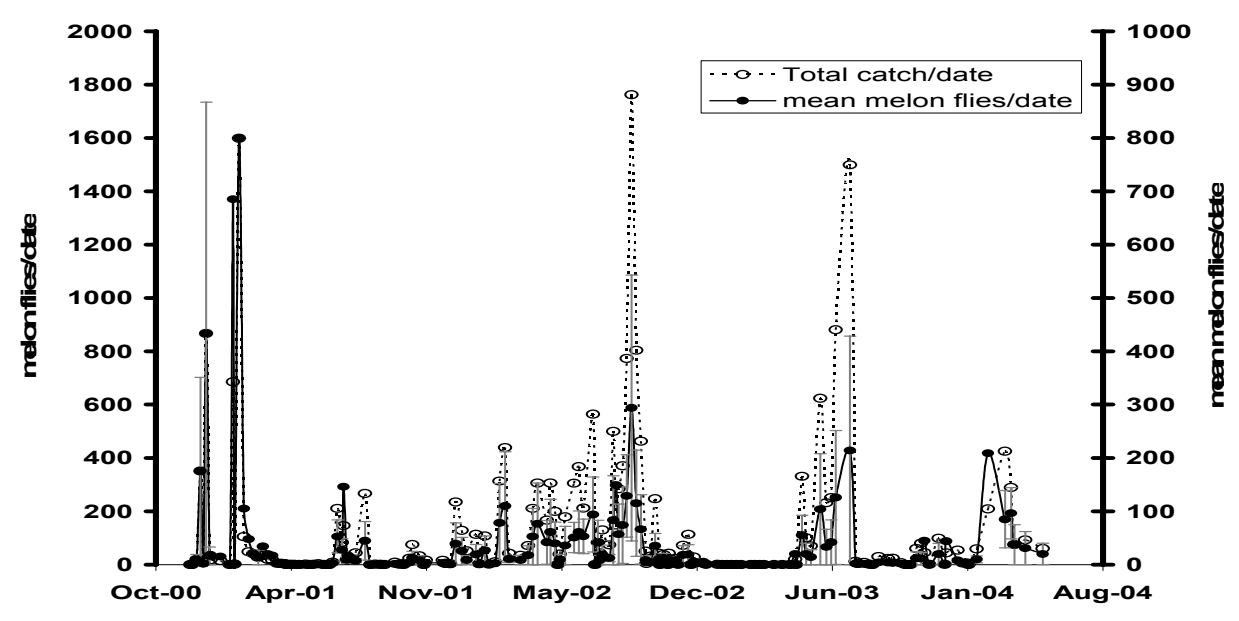

Fig. 6. Total and mean \pm s.e.m. emergence of $B$. cucurbitae from 15 augmentoria over the sampling dates. 


\section{REFERENCES}

Capinera, J. L. (2005). Pickleworm, Diaphania nitidalis (Stoll) (Insecta: Lepidoptera: Pyralidae). EENY-164.University of Florida, Institute of Food and Agricultural Sciences. Found on: http://edis.ifas.ufl.edu/IN321

Ebling, W.; Nishida, T.; Bess, A. H. (1953). Field experiments on the control of the melon fly, Dacus cucurbitae, Hilgardia. 21:17, 569-572.

Griesbach, J. (2003). Mango growing in Kenya. World Agroforestry Center (ICRAF) Klu Graphics, Nairobi, Kenya. 122 pp.

Haramoto, F. H.; Bess, H. A. (1970). Recent studies on the abundance of the Oriental and Mediterranean fruit flies and the status of their parasitoids. Proc. Hawaiian Entomol. Soc. 20(3):551-566.

Follett P.A.; Gabbard; Z. (2000). Effect of Mango Weevil (Coleoptera: Curculionidae) Damage on Mango Seed Viability in Hawaii. J. Econ. Entomol. 93(4):1237-1240.

Kaiser, I. (1968) Residual effectiveness of foliar sprays against the Oriental fruit fly, melon fly, and Mediterranean fruit fly, J. Econ. Entomol. 61:2 438-443.

Klungness, L. M.; Messing, R. H. (1999). Proposal to develop augmentorium, Low Input Sustainable Agriculture Program, University of Hawaii.

Klungness, L. M.; Jang, E. B.; Mau, R. F. L.; Vargas, R. I.; Sugano, J. S.; Fujitani, E. (2005). Sanitation techniques for controlling tephritid fruit flies (Diptera: Tephritidae) in Hawaii. J. Appl. Sci. \& Environ. Manage. 9 (2) 5-14.

Liquido, N. J. (1991a). Fruit on the ground as a reservoir of resident melon fly (Diptera: Tephritidae) population in Papaya orchards. Environ. Entomol. 20:2, 620-625.

Liquido, N. J. (1991b). Indices of density and percentage infestation of Oriental fruit fly and melon fly (Diptera:Tephritidae) in 'Waimanalo' papaya, J. Plant Protection in Tropics. 8:3 145-152.

Liquido, N. J. (1993). Reduction of Oriental fruit fly (Diptera:Tephritidae) populations in Papaya orchards by field sanitation. J. Agric. Entomol. 10:3 163-170.

Medley, T. (1998). Importation of Fruits and Vegetables; Papayas From Brazil and Costa Rica. Federal Register Evironmental Documents, Environ. Protection Agency. Docket No. 96-046-5. Available at: http://www.epa.gov/fedrgstr/EPAGENERAL/1998/March/Day-13/g6536.htm

Miller, N.W.; Vargas, R.I.; Prokopy, R.J.; Mackey, B.E. (2004). State-dependent attractiveness of protein bait and host fruit odor to Bactrocera cucurbitae (Diptera: Tephritidae) females. Annals of the Entomological Society of America. 94:5 p. 1063-1068(6).

Nishida, T. (1954). Further studies on the treatment of border vegetation for melon fly control. J. Econ. Entomol. 47:2, 226-229.

Nishida, T. (1958). The influence of yeast hydrolysate on the behavior of the melon fly. J. Econ. Entomol. 51:2, 140-143.

Nishida, T.; Bess, H. A. (1950). Applied ecology in melon fly control. J. Econ. Entomol. 43:6, 877-883.

Nishida, T.; Bess, H. A.; Ota, A. (1957). Comparative effectiveness of malathion and malathion-yeast hydrolysate bait sprays for control of the melon fly. J. Econ. Entomol. 50:5. 680-684.

Prokopy, R.J.; Miller, N.W.; Pinero, J.C.; Barry, J.D.; Tran, L.C.; Oride, L.K.; Vargas, R.I. (2003). Effectiveness of GF-120 fruit fly bait spray applied to border area plants for control of melon flies (Diptera: Tephritidae). Journal of Economic Entomology. 96(5):1485-1493.

Prokopy, R.J.; Miller, N.W.; Pinero, J.; Oride, L.K.; Chaney, N.L.; Revis, H.; Vargas, R.I. (2005). How effective is GF-120 fruit fly bait spray applied to border area sorghum plants for control of melon flies (Diptera: Tephritidae). Florida Entomologist. 87:3. P354-360.

Purcell, M. F.; Jackson, C. G.; Long, J. P.; Batchelor, M. A. (1994a). Influences of guava ripening on parasitism of the Oriental fruit fly, Bactrocera dorsalis (Hendel) (Diptera:Tephritidae), by Diachasmimorpha longicaudata (Ashmead) 
(Hymenoptera:Braconidae) and other parasitoids. Biological Control 4, 396-403.

Purcell, M. F.; Stark, J. D.; Messing, R. H. (1994b). Insecticide effects on three tephridid fruit flies and associated braconid parasitoids in Hawaii, J. Econ. Entomol. 87:6, 1455-1462.

Purcell, M. F.; Johnson, M. W.; Tabashnik, B. E. (1995). Effects of insecticide use on abundance and diversity of tomato pests and associated natural enemies in Hawai'i. Proc. Hawaii. Entomol. Soc. 32: 45-59.

Purcell, M. F.; Messing, R. H. (1996a). Ripeness effects of three vegetable crops on abundance of augmentatively released Psytallia fletcheri: improved sampling and release methods. Entomophaga. 41:105-115.

Purcell, M. F.; van Nieuwenhoven, A.; Batchelor, M. A. (1996b). Bionomics of Tetrastichus giffardianus (Hymenoptera: Eulophidae): An endoparasitoid of Tephritid fruit flies. Environ. Entomol. 25(1):198206.
Purcell, M. F. (1998). Contribution of biological control to integrated pest management of tephritid fruit flies in the tropics and subtropics. Integrated Pest Manage. Rev. 3, 63-83.

Revis, H.C.; Miller, N.W.; Vargas, R.I. (2004). Effects of aging and dilution on attraction and toxicity of GF-120 fruit fly bait spray for melon fly control in Hawaii. Journal of Economic Entomology. 97(5):P1659-1665.

Vargas, R. I.; Miller, N. W.; Long, J.; Delate, K.; Jackson, C. G.; Uchida, G.; Bautista, R. C.; Harris, E. J. (2004). Releases of Psyttalia fletcheri (Hymenoptera: Braconidae) and sterile flies against melon fly (Diptera: Tephritidae) in Hawaii. J. Econ. Entomol. 97: 1531 - 1539.

Vargas, R. I.; Miyashit;, D.; Nishida, T. (1984). Life history and demographics of three laboratoryreared tephritids (Diptera: Tephritidae) Ann. Entomol. Soc. Am. 77, 651-656 